\title{
PENGARUH MODEL PEMEBLAJARAN GI BERBANTUAN MEDIA PEMBELAJARAN TERHADAP KEMAMPUAN PEMECAHAN MASALAH MATEMATIKA DITINJAU DARI KEMAMPUAN AWAL MATEMATIKA
}

\author{
Nikmawati A. Sude ${ }^{1}$, Ismail Djakaria ${ }^{2}$, Tedy Machmud ${ }^{3}$ \\ J1. Jend. Sudirman No. $6^{1,2,3}$ \\ nikmawatiabubakar@gmail.com
}

\begin{abstract}
Abstrak
Tujuan penelitian ini adalah untuk mengetahui perbedaan kemampuan pemecahan masalah matematika yang dibelajarkan dengan model group investigation berbantuan media dan model pembelajaran langsung berbantuan media ditinjau dari kemampuan awal matematika. Metode penelitian ini adalah metode eksperimen dengan desain treatment by level $2 \times 2$. Data penelitian diperoleh melalu tes kemampuan pemecahan masalah matematika dan tes kemampuan awal matematika. Analisis data kemampuan pemecahan masalah matematika yang pengelompokkannya didasarkan pada skor tes kemampuan awal matematika yang menjadi variabel moderator mencakup kemampuan awal matematika tinggi dan kemampuan awal matematika rendah. Data penelitian di analisis dalam dua bagian yakni analisis deskriptif dan analisis inferensial. Penelitian ini menghasilkan temuan yakni : (1) Model pembelajaraan kooperatif tipe group investigation berbantuan media pembelajaran dipandang cocok dalam membelajarkan PLSV dan PtLSV di kelas VII pada tingkat Sekolah Menengah Pertama daripada model pembelajaran langsung berbantuan media pembelajaran. (2) Model pembelajaraan kooperatif tipe group investigation berbantuan media pembelajaran dipandang cocok dalam membelajarkan PLSV dan PtLSV di kelas VII pada tingkat Sekolah Menengah Pertama daripada model pembelajaran langsung berbantuan media pembelajaran pada kelompok peserta didik yang memiliki kemampuan awal matematika tinggi. (3) Model pembelajaraan kooperatif tipe group investigation berbantuan media pembelajaran dan model pembelajaran langsung berbantuan media pembelajaran dipandang cocok dalam membelajarkan PLSV dan PtLSV di kelas VII pada tingkat Sekolah Menengah Pertama pada kelompok peserta didik yang memiliki kemampuan awal matematika rendah.

Kata Kunci : Model Pembelajaraan Kooperatif Tipe Group Investigation, Model Pembelajaran Langsung, Kemampuan Pemecahan Masalah Matematika, Kemampuan Awal Matematika.
\end{abstract}

\begin{abstract}
The purpose of this study was to determine the differences in the ability to solve mathematical problems taught by the media-assisted group investigation model and the media-assisted direct learning model in terms of the initial mathematical abilities. This experimental research employed a treatment design by level $2 \times 2$. The research data were obtained through tests of mathematical problemsolving abilities and tests of initial mathematics abilities. Data analysis of mathematical problem-solving abilities were grouped based on the initial mathematics ability test score (moderating variable), including high initial mathematics ability and low initial mathematics ability. The research data were analyzed in two parts, namely, descriptive analysis and inferential analysis. This study resulted in the following findings: (1) The cooperative learning model type group investigation assisted by learning media was deemed suitable in teaching PLSV and PtLSV in seventh-grade students at the junior high school level rather than the direct learning model assisted by learning media. (2) The cooperative learning model type group investigation assisted with learning media was considered
\end{abstract}


suitable in teaching PLSV and PtLSV in seventh-grade students at the junior high school level to groups of students with high initial mathematical abilities. (3) Both of the learning models were deemed suitable in teaching PLSV and PtLSV in seventh-grade students at the junior high school level in groups of students with low initial mathematical abilities.

Keywords: Cooperative Learning Model Type Group Investigation, Direc Learning Model, Mathematical Problem-Solving Ability, Initial Mathematics Ability. 


\section{PENDAHULUAN}

Matematika merupakan salah satu bidang yang memiliki peranan penting dalam pendidikan. Untuk mempelajari suatu materi matematika yang baru, maka pengalaman belajar dari seseorang itu akan mempengaruhi proses belajar matematika tersebut, terlebih dahulu harus menguasai materi sebelumnya karena kontinuitas dari materi tersebut. Sehingga kemampuan awal yang dimiliki berperan penting dalam memecahkan masalah yang dihadapi.

Pemecahan masalah merupakani proses berfikir tingkat tinggi yang memerlukan pemahaman serta solusi jawaban yang kompleks. Kemampuan kemampuan yang lebih terkontrol dan mendasar. Hal yang termasuk mencerminkan langkah - langkah pemecahan masalah ini adalah penemuan masalah dan perumusan masalah Jihad [1].

Dengan demikian untuk dapat memecahkan suatu permasalahan matematika, peserta didik dituntut untuk aktif dan memiliki strategi agar dapat menyelesaikan soal - soal ataupun masalahmatematika yang diberikan.

Media memiliki peran untuk menunjang proses pembelajaran, salah satunya mengatasi kejenuhan peserta didik dalam belajar serta dengan adanya media dapat memebantu menanamkan pemahaman konsep yang akan diajarkan. Sehingga dengan adanya penggunaan media pada proses pembelajaran diharapkan akan tercipta suatu proses belajar mengajar yang aktif, efektif dan efesien.

Dalam kegiatan belajar mengajar tidak dapat dipungkiri bahwa diantara peserta didik yang satu dengan yang lainnya memiliki perbedaan selama kegiatan pembelajaran, baik itu secara individu ataupun dalam kelompok. Dalam rangka penguasaan matematika, salah satu kemampuan matematis yang seharusnya dimiliki oleh peserta didik yakni kemampuan awal matematis peserta didik itu sendiri, sehingga memudahkan mereka untuk memecahkan masalah yang diberikan, untuk masing-masing setiap individu ataupun permasalahan yang diberikan dalam kelompok.

Akan tetapi kenyataannya kemampuan pemecahan masalah belum sesuai dengan yang diharapkan. Dikutp dari Pusat Penilaian Pendidikan, Kementerian Pendidikan dan Kebudayaan tentang Hasil Ujian Nasional mata pelajaran matematika memiliki nilai rata - rata terendah yaitu 45,13 pada tahun 2018 dan 46,19 pada tahun 2019 pada tahun 2018 dan 2019 tingkat SMP. Hasil rata - rata yang diperoleh ini merupakan hasil UNBK (UJian Nasional Berbasis Komputer). Hal ini juga terlihat pada peserta didik di SMP Negeri 4 Gorontalo yang berdasarkan informasi dari seorang guru matematika bahwa kemampuan pemecahan masalah maetmatis peserta didik di sekolah ini masih kurang. Dapat diamati masih adanya peserta didik yang ketika guru menanyakan materi yang telah dijelaskan mereka tidak mampu untuk mengingat apalagi menjelaskan kembali, sehingga berdampak juga pada nilai akhir semester peserta didik, yang seharunya Kritereria Ketuntasan Minimal Mata Pelajaran Matematika 75, tetapi dari data Nilai Ulangan Semester Genap 2018-2019 yang diambil pada kelas VII4, VII-8, dengan jumlah siswa tidak tuntas 12 dan 14 orang yang rata-rata nilainya 
hanya 30.79 dan 33.14, sebelum remedi. Menurut informasi yang diperoleh, selama 1 semester guru kurang memvariasikan berbagai model dengan media pembelajaran selama kegiatan belajar mengajar pada mata pelajaran matematika kelas VII.

Beberapa faktor yang menjadi penyebabnya adalah penggunaan model dan media yang tidak singkron dengan materi yang akan diajarkan. Salah satu model pembelajaran yang bisa digunakan adalah kooperatif tipe Group Investigation. Pada model pembelajaran kooperatif tipe group investigation, dapat membantu peserta didik memahami topik-topik pembelajaran, secara aktif mendorong peserta didik untuk belajar serta bagaimana mendapatkan pengetahuan dari penyelidikan yang peserta didik lakukan. Peserta didik bukan hanya dituntut untuk bekerja sama didalam Group Investigation, tetapi juga saling membantu memecahkan topik permasalah yang diberikan maupun mencari konsep yang tepat untuk proses investigatif dalam pemecahan masalah. Selain itu dapat dibantu dengan media pembelajaran yang cocok sehingga peserta didik dapat lebih mudah memahami dan mengingat konsep yang dapat mereka gunakan.

Hal ini didukung juga oleh beberapa teori, menurut Saputra [2] Aspek rasa sosial dari kelompok serta pertukaran intelektual dapat bertindak sebagai sumbersumber penting bagi peserta didik untuk belajar. Dan menurut Harahap [3] Guru yang menggunakan pendekatan Group Investigation biasanya membagi kelasnya menjadi kelompok-kelompok heterogen yang masing-masing beranggota lima atau enam orang. Siswa memilih topik-topik untuk dipelajari, melakukan investigasi mendalam terhadap sub-sub topik yang dipilih, dan kemudian menyiapkan dan mempresentasikan laporan kepada seluruh kelas. Peserta didik dalam kelompok juga diberi kesempatan untuk menentukan cara menyelesaikan tugas. Peserta didik juga melakukan interpretasi hasil penyelidikan yang mungkin berbeda satu dengan yang lainnya sehingga memperoleh suatu pemikiran utuh yang kemudian mereka tuangkan ke dalam penyelesaian tugas kelompok. Hal ini menuntut peserta didik untuk berpikir tinggi dan kritis.

Terkait dengan penjelasan diatas, peneliti tertarik untuk melakukan penelitian eksperimen pada pembelajaran matematika dengan menerapkan Model Pembelajaran Kooperatif tipe Group Investigation. Peneliti ingin melakukan penelitan dengan judul "Pengaruh Model Pembelajaran Kooperatif Tipe Group Investigation Berbantuan Media Pembelajaran Terhadap Kemampuan Pemecahan Masalah Ditinjau Dari Kemampuan Awal"

\section{METODE}

Penelitian ini dilaksanakan di SMP Negeri 4 Gorontalo Jl. Beringin Kelurahan Buladu Kecamatan Kota Barat Kota Gorontalo Provinsi Gorontalo, pada semester ganjil tahun pelajaran 2019 - 2020. Penelitian ini merupakan penelitian eksperimen dengan paradigma kuantitatif. Desain eksperimen yang digunakan dalam penelitian ini adalah eksperimen treatment by level. Faktor pemilahnya adalah variabel moderator kemampuan awal matematika. 
Pengelompokkan terdiri atas dua tingkatan yaitu kemampuan awal matematika tinggi dan kemampuan awal matematika rendah. Yang masing - masing dikelompokkan berdasarkan pembagian kemampuan awal matematika tinggi $(\bar{X}+S D)$ dan kemampuan awal matematika rendah $(\bar{X}-S D)$. Teknik pengumpulan data dalam penelitian ini menggunakan tes esay. Teknik analisis yang digunakan dalam penelitian ini adalah teknik analisis deskriptif dan analisis inferensial. Untuk keperluan pengujian hipotesis digunakan analisis varians dua jalur (ANAVA $2 \times 2$ ). Analisis varian yang digunakan dalam pengujian ini adalah $\mathrm{Uji}-\mathrm{F}$.

\section{HASIL DAN PEMBAHASAN}

Hasil dari penelitian diringkas dalam bentuk rekap ukuran statistik data seperti pada Tabel 1.

Tabel 1. Deskripsi Hasil Belajar Matematika

\begin{tabular}{|c|c|c|c|c|c|c|c|c|}
\hline Data & $\mathbf{N}$ & $\begin{array}{c}\text { Skor } \\
\text { Min }\end{array}$ & $\begin{array}{c}\text { Skor } \\
\text { Maks }\end{array}$ & Mean $(\overline{\mathbf{Y}})$ & $\begin{array}{c}\text { Modus } \\
(\mathbf{M o})\end{array}$ & $\begin{array}{c}\text { Median } \\
(\mathbf{M e})\end{array}$ & Varians & $\begin{array}{c}\text { St. Deviasi } \\
(\mathbf{s})\end{array}$ \\
\hline$A_{l}$ & 40 & 19 & 59 & 41,78 & 49,79 & 45,3 & 132,89 & 11,53 \\
\hline$A_{2}$ & 42 & 20 & 53 & 35,92 & 27,9 & 35,1 & 101,52 & 10,08 \\
\hline$B_{1}$ & 41 & 20 & 59 & 41,44 & 50,51 & 42,25 & 119,45 & 10,92 \\
\hline$B_{2}$ & 41 & 19 & 53 & 36,13 & 28,1 & 35,24 & 108,08 & 10,4 \\
\hline$A_{l} B_{l}$ & 20 & 40 & 59 & 50,30 & 53,5 & 51,5 & 33,01 & 5,75 \\
\hline$A_{2} B_{l}$ & 21 & 20 & 49 & 32,79 & 29,7 & 32,1 & 58,11 & 7,6 \\
\hline$A_{l} B_{2}$ & 20 & 19 & 52 & 33,55 & 27,69 & 31,31 & 104,58 & 10,22 \\
\hline$A_{2} B_{2}$ & 21 & 24 & 53 & 37,79 & 50,26 & 36 & 98,91 & 9,94 \\
\hline
\end{tabular}

Dengan ringkasan Anava 2 jalur dan uji t-berpasangan yang dapat dilihat pada Tabel 2 dan Tabel 3

Tabel 2. Hasil Perhitungan ANAVA 2 x 2 Data Hasil Belajar Matematika

\begin{tabular}{|c|c|c|c|c|c|}
\hline Sumber Variansi & JK & $\mathrm{dk}$ & $\mathrm{RJK}$ & $\mathrm{F}_{\text {hitung }}$ & $\mathrm{F}_{\text {tabel }}(\alpha=0,05)$ \\
\hline Antar Model Pembelajaran & 595,32 & 1 & 595,32 & 6,54 & 3,96 \\
\hline $\begin{array}{c}\text { Antar Model Pembelajaran } \\
\text { dan Kemampuan awal }\end{array}$ & 1353,92 & 1 & 1353,92 & 14,87 & 3,96 \\
\cline { 1 - 4 } Dalam (D) & 7101,91 & 78 & 91,05 & \multicolumn{2}{|}{} \\
\hline Total (T) & 9051,15 & 82 & 2040,29 & & \\
\hline
\end{tabular}

Tabel 3. Hasil Perhitungan Uji t-berpasangan

\begin{tabular}{|c|c|c|c|c|}
\hline No & Kelompok & $\mathbf{t}_{\text {hitung }}$ & $\mathbf{t}_{\text {tabel }(\mathbf{a}=\mathbf{0 , 0 5})}$ & Kesimpulan \\
\hline 1. & $\mathrm{~A}_{1} \mathrm{~B}_{1}$ dengan $\mathrm{A}_{2} \mathrm{~B}_{1}$ & 5,9 & 2,02 & Signifikan \\
\hline 2. & $\mathrm{~A}_{2} \mathrm{~B}_{2}$ dengan $\mathrm{A}_{1} \mathrm{~B}_{2}$ & 1,43 & 2,02 & Tidak Signifikan \\
\hline
\end{tabular}

1. Perbedaan kemampuan pemecahan masalah matematika antara peserta didik yang dibelajarkan dengan Model Group Investigation dan Peserta Didik yang Dibelajarkan dengan Model pembelajaran langsung berbantuan media pembelajaran 
Dengan menggunakan uji ANAVA dua jalur menunjukkan bahwa rata-rata skor kemampuan pemecahan masalah pada peserta didik yang dibelajarkan dengan model pembelajaran Group Investigation berbantuan media pembelajaran lebih tinggi dibandingkan rata-rata kemampuan pemecahan masalah peserta didik yang dibelajarkan dengan model pembelajaran langsung berbantuan media pembelajaran. Hal ini dapat dilihat dari hasil capaian kemampuan pemecahan masalah matematika berdasarkan data yang telah dikelompokkan berdasarkan tingkat kemampuan awal matematika yang dimiliki oleh peserta didik, baik kemampuan awal matematika tinggi maupun kemampuan awal matematika rendah.

Pada model pembelajaran Group Investigation merupakan salah satu model pemeblajaran yang dilandasi oleh kemampuan peserta didik dalam kerja kelompok untuk memecahkan permasalahan melalui pengalamanpengalaman peserta didik ataupun konsep-konsep yang telah peserta didik kuasai, sehingga memudahkan dalam menemukan solusi. Mereka diberikan sebuah masalah melalui penayangan vedio dan LKPD, dimana setiap kelompok memiliki permasalahan yang berbeda untuk mereka selesaikan.

Berbeda dengan pembelajaran langsung, pada pembelajaran ini selain menerima penjelasan materi langsung dari guru, peserta didik dibantu dengan media vedio yang sama tetapi tidak dibentuk dalam kelompok, sehingga mereka hanya bisa menggunakan pengalaman atau pengetahuan awal masingmasing untuk memecahkan masalah matematika yang diberikan.

Dari uraian di atas menunjukkan bahwa model Group investigation baik dari segi tahapan pembelajaran maupun dari bahan ajar yang digunakan oleh guru lebih membantu peserta didik dalam memecahkan permasalahan matematika. Selain itu, peserta didik merasa memiliki pengalaman baru dengan adanya kegiatan pembelajaran yang menerapkan model Group Investigation berbantuan media pembelajaran. Ini menunjukkan bahwa model Group Invetigation bisa dijadikan sebagai model pembelajaran di Kelas VII SMP khususnya dalam penerapan kurikulum 2013.

2. Pengaruh Interaksi Antara Model Pembelajaran berbantuan media pembelajaran dan Kemampuan awal terhadap kemampuan pemecahan masalah matematika peserta didik

Hasil pengujian hipotesis kedua menunjukkan bahwa terdapat pengaruh interaksi antara model pembelajaran dan kemampuan awal terhadap kemampuan pemecahan masalah peserta didik. Hal ini memungkinkan terjadi jika pemilihan model pembelajaran yang tepat, penggunaan media pembelajaran dan juga kemampuan awal peserta didik karena akan sangat berpengaruh terhadap pencapaian tujuan pembelajaran.

Model pembelajaran Group Investigation merupakan model pembelajaran yang memberikan kesempatan bagi peserta didik untuk mengeksplor kemmapuan yang mereka miliki untuk memecahkan permasalahan matematika, sehingga dapat dikatakan bahwa kemampuan awal yang dimiliki pesrta didik memegang peran penting dalam proses pemecahan masalah matematika. Hal ini sejalan dengan pernyataan (Sumarmi 2012:124) 


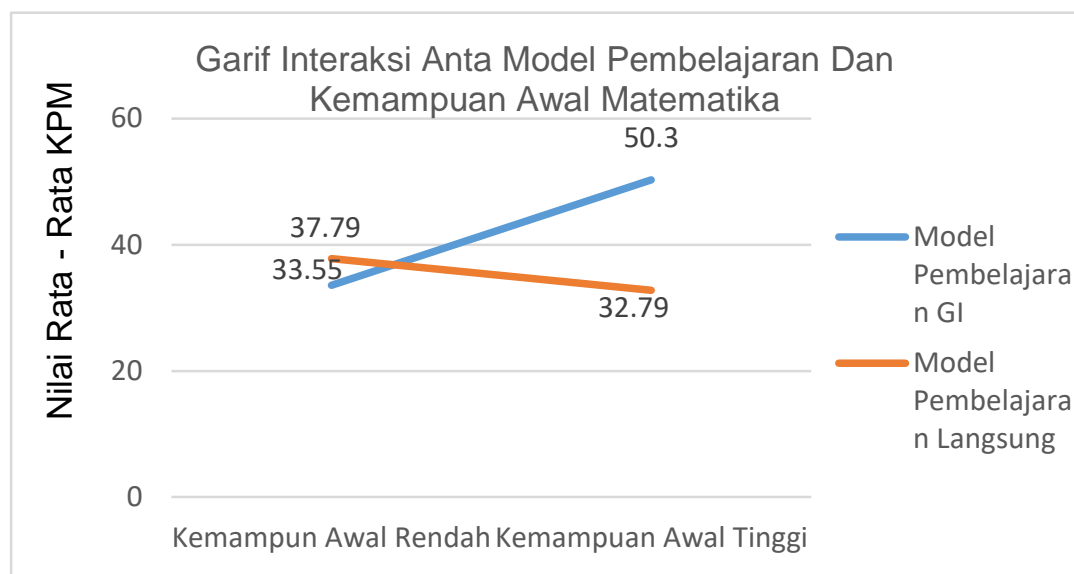

bahawa model

Group

Investigation

penerapanya

memungkinkan

peserta didik

untuk

menggunakan

kemampuan

yang mereka

miliki dalam

menemukan jawaban dari permasalahan. Dengan bantuan penggunaan media pembelajaran perta didik dapat diberikan bayangan dalam menemukan solusi, dan menarik keinginan peserta didik untuk mencari pemecahan masalah matematika dengan mengandalkan kemampuan awal mereka serta kerja sama kelompok.

Di dalam proses pembelajaran menggunakan model pembelajaran langsung berbantuan media pembelajaran, peserta didik dibantu dengan penyampain guru tentang materi yang diajarkan selain menggunakan media vedio, pada proses ini peserta didik yang memiliki kemampuan awal tinggi akan lebih cepat atau mudah memahami penyampaian guru, tetapi tidak menutup kemungkinan dengan peserta didik yang memiliki kemampuan awal rendah, karena sebelum diberikan soal untuk melihat kemampuan pemcahan masalaha matematika, peserta didik telah dibantu dengan media yang digunakan oleh guru.

Gambar 1. Interaksi antara Model Pembelajaran berbantuan media dan Kemampuan Awal Matematika terhadap Kemampuan Pemecahan Masalah Matematika

Gambar 1 di samping menunjukkan hasil kemampuan pemcahan masalah matematika yang mempunyai kemampuan awal matematika tinggi yang dibelajarkan menggunakan model Group Investigation (garis biru) lebih tinggi daripada yang dibelajarkan dengan model Pembelajaran Langsung (garis orange). Sedangkan Untuk kemampuan awal rendah nilai perolehan rata- rata kemampuan pemecahan masalah peserta didik pada model Pembelajaran Langsung (garis orange) lebih tinggi dibandingkan dengan model pembelajaran Group Investigation (garis biru).

Sehingga dapat dikatakan ada pengaruh interaksi antara kedua model pembelajaran dengan kemampuan awal matematika yang dimiliki peserta didik terhadap hasil belajar matematika. Temuan ini menunjukkan bahwa hipotesis penelitian yang diajukan teruji kebenarannya.

3. Kemampuan pemecahan masalah berbantuan media pembelajaran yang dibelajarkan dengan model Group Investigation lebih tinggi dari model 


\section{pembelajaran langsung pada peserta didik yang memiliki kemampuan awal tinggi}

Pengujian hipotesis ketiga ini dilakukan dengan membandingkan skor rata - rata kemampuan pemecahan masalah matematika yang dibelajarkan dengan model group investigation berbantuan media pembelaajran dan memiliki kemampuan awal matematika tinggi $\left(\bar{X} A_{1} B_{1}\right)$ dengan skor rata rata kemampuan pemecahan masalah matematika kelompok yang dibelajarkan dengan model pembelajaran langsung berbantuan media pembelajaran dan memiliki kemampuan awal matematika tinggi $\left(\bar{X} A_{2} B_{1}\right)$. Hasil analisis dengan uji $t$-berpasangan untuk kelompok peserta didik $\left(A_{1} B_{1}\right)$ yang memiliki kemampuan awal matematika tinggi menunjukkan, bahwa model group investigation memberikan pengaruh yang lebih baik terhadap hasil kemampuan pemecahan masalah matematika dibandingkan dengan model pembelajaran langsung $\left(A_{2} B_{1}\right)$. Ini terbukti bahwa $\mathrm{t}_{\text {hitung }}=5,09>\mathrm{t}_{\text {tabel }}=$ $2,03(\alpha=0,05)$. Juga nilai rata - rata kemampuan pemecahan masalah matematika dari kelompok $\mathrm{A}_{1} \mathrm{~B}_{1}(\bar{X}=50,30)$ lebih tinggi dari kelompok $\mathrm{A}_{2} \mathrm{~B}_{1}$ $(\bar{X}=32,79)$. Artinya, hipotesis ini diterima atau teruji secara signifkan.

Dalam model pembelajaran Group investigation peserta didik aktif secara berkelompok melakukan kegiatan pembelajaran, dan dengan bantuan media pembelajaran peserta didik bisa saling membagi pengetahuan yang mereka miliki untuk membahas permasalahan yang ditampilkan, khusunya penguasaan materi prasyarat. Sedangkan pada model pembelajaran langsung dirancang untuk membantu peserta didik belajar secara terstruktur tahap demi tahap tentang pengetahuan dan keterampilan yang secara garis besarnya melalui bantuan media pembelajaran, latihan terstruktur dan latihan mandiri yang dapat membantu peserta didik untuk belajar sesuatu yang kompleks dengan baik, dan mengandalkan kemampuan penguasaan materi prasyrat mereka sendiri.

Dari hasil analisis data, telah teruji bahwa peserta didik yang memiliki kemampuan awal tinggi sangat cocok dibelajarkan dengan model pembelajaran Group Investigation berbantuan media pembelajaran dalam mengembangkan pengalaman belajar matematikanya.

4. Kemampuan pemecahan masalah berbantuan media pembelajaran yang dibelajarkan dengan model Group Investigation lebih rendah dari model pembelajaran langsung pada peserta didik yang memiliki kemampuan awal rendah

Pengujian hipotesis keempat ini dilakukan dengan membandingkan skor rata - rata kemampuan pemecahan masalah matematika yang dibelajarkan dengan model group investigation dan memiliki kemampuan awal matematika rendah $\left(\bar{X} A_{1} B_{2}\right)$ dengan skor rata - rata kemampuan pemecahan masalah matematika yang dibelajarkan dengan model pembelajaran langsung dan memiliki kemampuan awal matematika rendah $\left(\bar{X} A_{2} B_{2}\right)$. Hasil analisis dari uji t-berpasangan untuk kelompok yang memiliki kemampuan awal matematika rendah $\left(\mathrm{A}_{2} \mathrm{~B}_{2}\right)$ menunjukkan, bahwa 
model pembelajaran langsung memberikan pengaruh yang sama terhadap kemampuan pemecahan masalah matematika dengan model group investigation $\left(\mathrm{A}_{1} \mathrm{~B}_{2}\right)$. Ini terbukti bahwa $\mathrm{t}_{\text {hitung }}=1,43 \leq \mathrm{t}_{\text {tabel }}=2,03(\alpha=0,05)$. Tetapi untuk nilai rata - rata hasil belajar matematika dari kelompok $\mathrm{A}_{2} \mathrm{~B}_{2}(\bar{X}$ $=37,79)$ lebih tinggi dari kelompok $\mathrm{A}_{1} \mathrm{~B}_{2}(\bar{X}=33,55)$. Berdasarkan hasil penelitian yang telah dilakukan menunjukkan bahwa skor rata-rata antara model pembelajaran langsung berbantuan media pembelajaran dan model group invetigation berbantuan media pembelajaran, lebih tinggi pada pembelajaran langsung, hal tersebut disebabkan karena kelompok peserta didik yang meiliki kemampuan awal rendah, akan termotivasi dengan bantuan penyampaian guru tentang materi yang diajarkan dan media yang digunakan, sedangkan jika diterapkan pada kelompok peserta didik yang dibelajarakan dengan GI berbantuan media peserta didik yang memilki kemampuan awal rendah akan sulit memberikan ide - ide dalam kelompok mereka, tetapi berdasarkan pengujian hipotesis teradapat adanya ketidak signifikan antara kedua kelompok kelas tersebut, peneliti berpendapat hal ini terjadi karena adanya pengaruh media yang sama - sama diterapkan untuk pembelajaran disetiap kelompok kelas, dapat dibandingkan dengan temuan Rustina[4]bahwa terdapat perbedaan yang signifikan antara kedua kelompok pembelajaran, yang memilki arti bahwa antara model pemebelajaran Group Investigation Berbantuan Media lebih baik dari Pemebelajaran Langsung. Sedangkan pada temuan penelitian ini kedua kelompok pembelajaran dibelajarkan dengan bantuan media, sejalan dengan pendapat Puyo [5] bahwa media pembelajaran memberikan pengaruh yang signifikan terhadap hasil belajar peserta didik.

Sehingga dapat dikatakan bahwa hipotesis keempat yang diajukan peneliti, tidak teruji kebenarnya, dengan kata lain model pembelajaran Group Investigation dan pembelajaran langsung, berbantuan media pembelajaran keduanya bisa digunakan pada peserta didik yang memiliki kemampuan awal rendah.

\section{KESIMPULAN}

Berdasarkan hasil penelitian dan hasil pengujian hipotesis seperti yang telah diuraikan, peneliti menyimpulkan bahwa: : (1) Model pembelajaraan kooperatif tipe group investigation berbantuan media pembelajaran dipandang cocok dalam membelajarkan PLSV dan PtLSV di kelas VII pada tingkat Sekolah Menengah Pertama daripada model pembelajaran langsung berbantuan media pembelajaran. (2) Model pembelajaraan kooperatif tipe group investigation berbantuan media pembelajaran dipandang cocok dalam membelajarkan PLSV dan PtLSV di kelas VII pada tingkat Sekolah Menengah Pertama daripada model pembelajaran langsung berbantuan media pembelajaran pada kelompok peserta didik yang memiliki kemampuan awal matematika tinggi. (3) Model pembelajaraan kooperatif tipe group investigation berbantuan media pembelajaran dan model pembelajaran langsung berbantuan media pembelajaran dipandang cocok dalam membelajarkan PLSV dan PtLSV di kelas VII pada tingkat Sekolah Menengah Pertama pada kelompok peserta didik yang memiliki kemampuan awal 
matematika rendah. Untuk pengembangan penelitian ini selanjutnya, diharapkan ada penelitian lanjutan pada mata pelajaran lain dengan melibatkan variabel moderator lain.

\section{DAFTAR RUJUKAN}

[1] Jihad, Asep. 2016. Peningkatan Kemampuan pemecahan masalah matematika Mahasiswa Melalui Pembelajaran Dengan Pendekatan Peta Konsep. Jurnal Analisa Volume II Nomor 3 September 2016 :Bandung

[2] Saputra, W. N. E. (2016). Jurnal Konseling dan Pendidikan. Jurnal Konseling Dan Pendidikan, 4(1), 39-45.

[3] Harahap, Ria Astri, Derlina. (2017). Pembelajaran Kooperatif Tipe Group Investigation (Gi) Dengan Metode Know-Want-Learn (Kwl): Dampak Terhadap Kemampuan pemecahan masalahFluida Dinamis. Medan: Jurnal Ilmiah Pendidikan Fisika Al-BiRuNi 06 (2) (2017) 149-158. P-ISSN: 23031832

[4] Rustina, Bagus, dkk. 2014. Pengaruh Model Pemeblajaran Group Investigation Berbantuan Media Konkrit Terhadap Hasil Belajar IPA Kelas V SD GUGUS II Tampaksirin. Universitas Ganesha, (Vol:2 No:1 Tahun 2014)

[5] Puyo, Dewi. 2009. Pengaruh Media Pemeblajaran Dan Motivasi Berprestasi Terhadap Hasil Belajar Matematika. Pascasarjana:UNG 